\title{
Differential preference for teaching methods among superficial and deep learners in a medical school in Malaysia
}

\author{
Latha Rajendra Kumar ${ }^{1}$, Sethuraman K.R. ${ }^{2}$
}

\begin{abstract}
Introduction: Learning approach by students may be by superficial learning or by deep learning where there is critical analysis of ideas. AIMST University follows hybrid curriculum with lectures, problem based learning (PBL), clinical bed side teaching and a structured clinical skill laboratory.
\end{abstract}

Design: Cross-sectional study

Participants: A total of 463 students (417 medical students and 46 dental students).

Main outcome measures: Learning approach (surface and deep learning style), preferred study habits, academic achievement.

Results: Positive correlation between deep approach learner and assessment and negative correlation between superficial approach learner and assessment was revealed.

Discussion: The deep approach learners preferred the PBL sessions and cited reasons they had the ability to gain more knowledge through self- directed learning.

Conclusion: Students should be motivated towards deep approach learning in order to enhance learning processes and for achieving greater academic success.

Keywords: problem based learning, simulator teaching, superficial and deep approach

\section{Introduction}

Learning Approach: Students approach their learning sometimes by surface approach where they see tasks as being imposed, for which they develop coping strategies focused on and memorizing information for assessment rather than for understanding (Evans, 2003), In deep approach learning students seek to understand ideas to allow them to integrate knowledge to develop conceptual frameworks. Learning approaches are different from learning styles (Kumar et al., 2009).

\footnotetext{
${ }^{1} M . D ., P h D$

Corresponding author:

Latha Rajendra Kumar, MD, PhD

FAIMER Fellow 2009, Fulbrighter 2012-13 (USA)

Director of Centre for Health Professional Education (HPE),

Convener of MEU,

Chairman of Board of Studies,

Convener of Student Mentor Program,

Professor and Head of Department of Physiology,

Yenepoya Medical College,Mangalore, India
}

Email: latha.rajendrakumar@gmail.com
Teaching methods and curriculum in AIMST University:

AIMST curriculum includes lectures and PBL for non-clinical students and clinical bed side teaching and clinical skill lab teaching for clinical students. In clinical skill lab teaching, hands on training are given to students from various mannequins' like Meti, Harvey, Robotic and Virtual reality simulators, housed in the clinical skill lab, one of the largest in Malaysia. A possible correlation between learning approach and teaching methods adopted by students may help curriculum planners to address any mismatch among learning approaches and instructional methods.

Assessment is by far the most important factor which drives students towards learning and achieving professional competence. The relation between learning approach of students and their academic achievement would throw light on the learning approaches to be adopted students to improve their academic performance. 


\section{Objectives}

- To assess existing learning styles and approaches of medical and dental students in AIMST using Biggs questionnaire

- To assess preferred teaching methods students' [lecture vs. PBL (knowledge domain); clinical skill lab vs. clinical bed side teaching (psychomotor domain].

- To determine whether there is a difference in the preference of teaching methods between deep and superficial learner.

- To look for correlation between the types of the learning approaches and performances in examination.

\section{Methods}

The project was placed in the Institutional Review Board of our University to get approval and ethical clearance.

Sample size: All medical and dental students were recruited for this study.

Process: Informed consent was received from the students. Questionnaires were distributed and a request was made to students to anonymously complete the form.

Participants: The undergraduate medical cohort comprised of 16 from batch 1, 40 from batch 2, 45 from batch 3, 30 from batch 4, 114 from batches 5, 660 from batch 7, 62 from batch 8 and 50 from batch 9 . The undergraduate dental students comprised of 46 students from batch 2 .

Respondents and Non-respondents: 463 out of 483 returned the completed questionnaire $(95.85 \%)$.

\section{Instrument:}

A. General Questionnaire was used to collect information students' name, age, sex, address, year of entering medical/dental school, present year of study in medical school. They were asked to choose whether they preferred PBL or lecture; preferred learning through simulation teaching in clinical skill lab or clinical bed side teaching in the hospital. The reasons why they liked or disliked a preferred method of teaching were elicited.

B. A 20-item in Biggs's Revised Study Process Questionnaire (R-SPQ-2F) was employed to measure students' learning methods/approaches. The Bigg's R-SPQ$2 \mathrm{~F}$ has 20 items. The psychometric properties (validity and reliability) of the SPQ-R-2F was verified by Biggs, Kember and Leung (2001); The envision process of the original SPQ resulted in the validation of a two-factor structure of learning approaches that correspond to two main learning styles: deep and surface. Other research studies have provided supporting evidence pertaining to the validation of the R-SPQ-2F, as well as, its effectiveness in evaluating students' learning approaches (Leung \& Kember, 2003; Skogsberg \& Clump, 2003).

C. The continuous assessment marks conducted at the end of each system of the students were also collected to be used as an indicator of achievement.

Statistical Analysis: Descriptive analysis of the data was done using SPSS (version 13.0). Independent $\mathrm{T}$ test was used to look at the relationship between methods of teaching (lectures, PBL, simulator and clinical bedside teaching) and types of learner (superficial and deep approaches). Karl's Pearson Correlation was used to look for a correlation between academic achievement and approach of learners.

\section{Results}

The sample was reasonably evenly distributed between male (42\%) and female (58\%) respondents. The average age of students in this study was approximately 23 years.

Results of Learning Approaches: More students adopted the surface approach (38.2\%) compared to the deep approach learning: (36.9\%). Students who were unsure of their approach or who use both styles were $24.8 \%$ items 1-20 score: a) High score in one $=$ preferred, b) high score in both = use both styles c) low score in both $=$ unsure or uninformed style).

Results of Preferred Teaching Methods: There were $52.7 \%$ of dental and medical students preferred lectures, $47.1 \%$ preferred the PBL sessions while $0.2 \%$ preferred both, $56.4 \%$ preferred clinical bed side teaching, $41.7 \%$ preferred simulator teaching in clinical skill lab while $1.9 \%$ preferred both.

Learning Approach and Assessment: Karl's Pearson Correlation revealed a significant positive correlation between high academic achievement and deep approach learners and a positive correlation between lower academic achievement and surface learners. $R$ value $=0.861$ for deep approach and marks and $R$ value $=-0.342$ for superficial approach and marks (Figure 1 and 2). 
Figure 1: Positive correlation between deep approach learner and assessment. ( $R$ value $=0.861$ by Karl's Pearson Correlation)

\section{MARKS AND DEEP APPROACH}

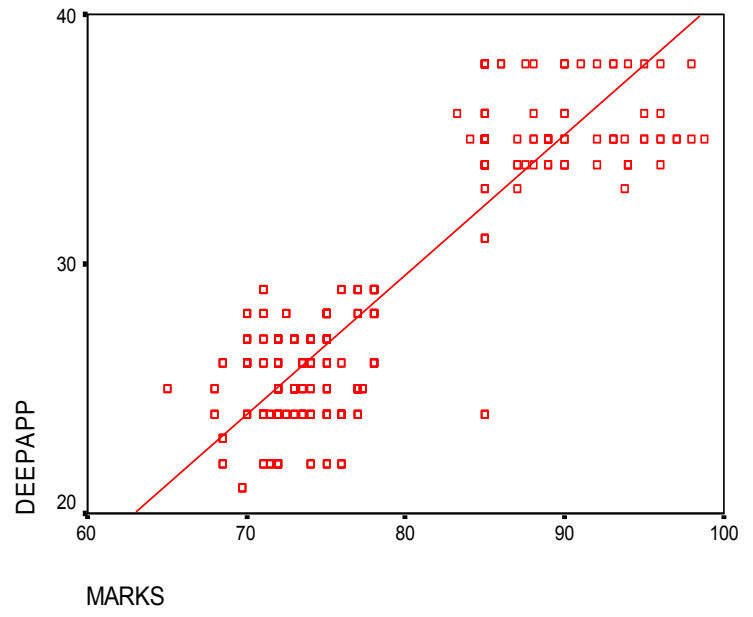

Figure 2: Negative correlation between superficial approach learner and assessment. ( $R$ value = - 0.342 by Karl's Pearson Correlation)

MARKS AND SUPERFICIAL APPROACH

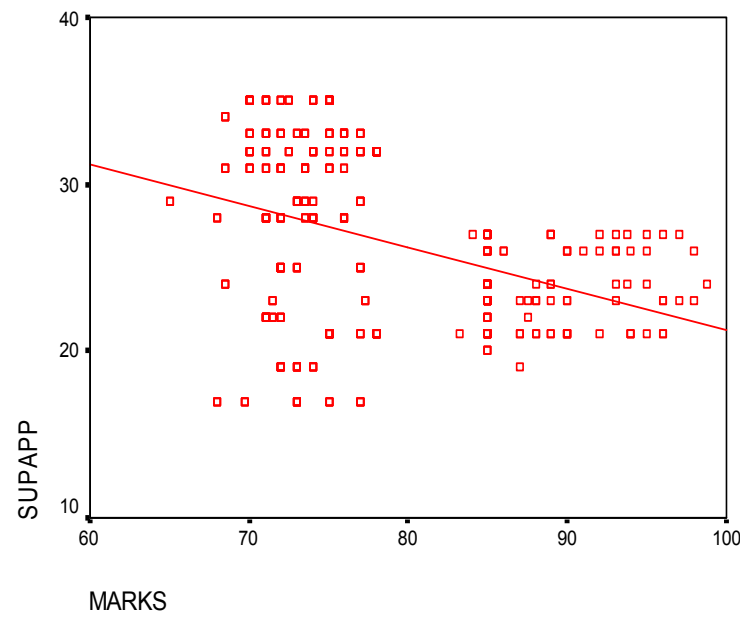




\section{Discussion}

Learning Approach and Teaching method: Independent Sample T Test revealed that:

1. Deep approach learning scores were significantly higher in students who liked PBL compared to lectures and in students who liked bed side teaching compared to simulator teaching in clinical skills lab.

2. Superficial approach learning scores were higher in students who liked lectures compared to PBL and significantly higher in students preferring (simulator teaching) in clinical skills lab compared to bed side teaching (Tables 1 and 2).

Understanding and acknowledging the learning approaches and teaching methods is the first step to teaching method management. The learning approaches were almost equally distributed in our student representative population with a slight higher trend towards superficial learning $(38.2 \%)$ in comparison to deep approach learning (36.9\%). A considerable population of students $(24.8 \%)$ fell in between superficial and deep approach of the learning arc.

The current teaching practices of our University were almost equally preferred by the students both traditional lectures and PBL with a slightly higher preference for lectures. The reasons cited by the students for preferring lectures were that all the topics were covered, notes were provided and students knew what to study, very similar to those reported by Lee Anderson (1990). Students preferred lecture because they are told about a subject by describing, explaining and giving examples. Students believed that lectures will relieve them of organizing and understanding the material of a course, as the content is predigested by the lecturer (Diana Laurillard, 1993).
Previous articles have compared problembased small-group learning with traditional lecture formats for medical students and found a greater satisfaction level with the former (Vernon and Blake, 1993; Wendelberger et al., 1996). The marginal higher preference $(52.7 \%)$ for lectures over PBL (47.1\%) could probably be the cause or effect of the marginal higher preference of superficial learner (38.2\%) compared to deep learner (36.9\%).

PBL is suitable for students who are selfdisciplined and take active responsibility for their own learning. Gibbs (1999) has reported that PBL fosters a deeper approach to learning, PBL promotes more versatile studying methods and PBL students are more likely to use the library and library resources to study and PBL develops greater knowledge retention and recall skills. Students' response in our study suggested that PBL could be a depletion of time, energy and efforts if they were not assessment oriented.

Similarly there was a slight more students who preferred clinical bed side teaching-learning when compared to simulator teachinglearning in the clinical skill lab. Clinical Skill Lab with a well-planned infrastructure, man power, technical assistance and incorporating OSPE (objectively structures and practical examination) and OSCE (objectively structured clinical examination) regularly, this trend may show a paradigm shift over a few years.

Assessment: According to Diseth (2005), the deep approach learners have shown greater academic achievement than in the past which was very similar to those revealed in our study. The probable mechanism of this could be the deep learner approach has interest subjects and focus its study on long term benefits and not merely to pass the examination.

Table 1: Learning approaches are compared with teaching methods (Lecture and PBL)

\begin{tabular}{lrrrrr}
\hline Variable & $\begin{array}{r}\text { Lectures } \\
\text { Mean (SD) }\end{array}$ & $\begin{array}{r}\text { PBL } \\
\text { Mean (SD) }\end{array}$ & $\begin{array}{r}\text { Mean Difference } \\
(95 \% \mathrm{Cl})\end{array}$ & T Test & P-Value \\
\hline $\begin{array}{l}\text { Deep Approach Learning } \\
\text { Scores }\end{array}$ & $26.74(3.78)$ & $29.79(5.08)$ & $-3.87,-2.24$ & -7.373 & $<0.001$ \\
$\begin{array}{l}\text { Superficial Approach } \\
\text { Learning Scores }\end{array}$ & $27.40(5.50)$ & $26.20(5.00)$ & $0.24,2.17$ & 2.451 & 0.015 \\
\hline
\end{tabular}


Table 2: Learning approaches are compared with teaching methods (Clinical bed side teaching and Clinical skill)

\begin{tabular}{llllll}
\hline Variable & $\begin{array}{l}\text { Simulator } \\
\text { Mean (SD) }\end{array}$ & $\begin{array}{l}\text { Bed side } \\
\text { teaching } \\
\text { Mean (SD) }\end{array}$ & $\begin{array}{l}\text { Mean } \\
\text { Difference } \\
\mathbf{( 9 5 \% ~ C l )}\end{array}$ & T Test & P-Value \\
\hline $\begin{array}{l}\text { Deep Approach } \\
\text { Learning Scores }\end{array}$ & $26.45(3.54)$ & $29.69(5.08)$ & $-3.90,-2.24$ & -7.287 & $<0.001$ \\
$\begin{array}{l}\text { Superficial } \\
\text { Approach Learning }\end{array}$ & $27.10(5.64)$ & $26.73(5.06)$ & $-0.62,1.36$ & 0.732 & 0.464 \\
\hline Scores & & & & & \\
\hline
\end{tabular}

Qualitative Data:

\begin{tabular}{|c|c|c|c|}
\hline \multicolumn{4}{|c|}{ Force Field Analysis of Students Response } \\
\hline \multicolumn{2}{|c|}{ Lectures } & \multicolumn{2}{|c|}{ PBL } \\
\hline Factors for & Factors against & Factors for & Factors against \\
\hline \multirow{2}{*}{$\begin{array}{l}\text { Easy to understand } \\
\text { Effective }\end{array}$} & Passive listening & Enjoyed & \multirow{2}{*}{$\begin{array}{l}\text { Involves individual } \\
\text { preparation and hard } \\
\text { work }\end{array}$} \\
\hline & Boring & More Involvement & \\
\hline \multirow{7}{*}{$\begin{array}{l}\text { Straight forward } \\
\text { Organized notes } \\
\text { Proper guidelines } \\
\text { provided } \\
\text { Covers all topics for } \\
\text { exams }\end{array}$} & & \multirow{2}{*}{$\begin{array}{l}\text { Good participation from } \\
\text { students }\end{array}$} & No sharing of material \\
\hline & No student participation & & Time for preparation is \\
\hline & \multirow{5}{*}{ Sleepy } & \multirow{2}{*}{$\begin{array}{l}\text { Improved knowledge } \\
\text { Thought provoking } \\
\text { Interesting }\end{array}$} & \multirow{2}{*}{$\begin{array}{l}\text { More pressure on small } \\
\text { group }\end{array}$} \\
\hline & & & \\
\hline & & Interactive & \multirow{3}{*}{$\begin{array}{l}\text { Cannot exhaustively } \\
\text { cover all topics }\end{array}$} \\
\hline & & $\begin{array}{l}\text { Can remember } \\
\text { information longer }\end{array}$ & \\
\hline & & Awake & \\
\hline \multicolumn{4}{|c|}{ Force Field Analysis of Students Response } \\
\hline \multicolumn{2}{|c|}{ Clinical bed side } & \multicolumn{2}{|c|}{ Clinical skill lab teaching } \\
\hline Factors for & Factors against & Factors for & Factors against \\
\hline \multirow{5}{*}{$\begin{array}{l}\text { Real life experience with } \\
\text { patients } \\
\text { More interesting } \\
\text { More effective }\end{array}$} & Tiring & \multirow{5}{*}{$\begin{array}{l}\text { Can practice repeatedly } \\
\text { which is not possible in } \\
\text { patients } \\
\text { Hands on training } \\
\text { Interesting to do lumbar } \\
\text { puncture, rectal } \\
\text { examination and hear } \\
\text { murmurs }\end{array}$} & \multirow{5}{*}{$\begin{array}{l}\text { No interaction with real } \\
\text { patients } \\
\text { Emotionally detached } \\
\text { Cannot talk to dummies } \\
\text { like to patients }\end{array}$} \\
\hline & Long hours of standing & & \\
\hline & Harsh teachers & & \\
\hline & Rude nursing staff & & \\
\hline & Patients complain & & \\
\hline
\end{tabular}

Note: Some students agreed that simulator and bed side teaching were complementary. 
Significance of the study: This paper has provided insights in to 4 popular areas: trends of curriculum, teaching-learning, attitudes of students and assessment. At the classroom level, there needs to be adjustments to the curriculum, the adoption of more inclusive approaches to teaching and learning, and the modification of teaching styles to accommodate students' diverse learning approaches.

Curricular changes recommended: $\mathrm{PBL}$ could be introduced with more uniformity and more number of contact hours. The simulated teaching in clinical skill lab could be modified to promote deep approach learning, by improving the element of "realism" associated with the mannequins.

\section{Future Directions:}

1. Help the superficial approach learner to become deep approach learner using appreciative inquiry.

2. Inclusion of PBL covered topics in assessments.

Conclusion: The learning approach and opinion on preferred teaching-learning methods may assist curriculum planners in fine tuning the teaching-learning methods.

\section{References:}

Biggs, J., Kember, D. \& Leung, D. Y. P. (2001) The revised two-factor Study Process Questionnaire: R - SPQ - 2F. British Journal of Educational Psychology, 71, pp.133-149.
Diana Laurillard, Rethinking University Education (1993) Routledge, ISBN 0 415-09289-2,

Diseth, A.(2005), European Journal of Personality, Volume 17, Issue 2, pp. 143-155.

Evans, C. J., Kirby, J. R.\& Fabrigar, L. R. (2003) Approaches to learning, need for cognition, and strategic flexibility among university students, Br J Educ Psychol. 73, pp. 507-28.

Gibbs, G. (1992) Improving the Quality of Student Learning, Technical and Educational Services Ltd, Bristol.

Kumar Latha Rajendra., K.Voralu , S. P. Pani \& K.R. Sethuraman., Predominant learning styles adopted by AIMST University students in Malaysia, South East Asian Journal of Medical Education, Volume 3, No 1, 2009.

Lee Andreson, Lecturing to large groups, in C. Rust, Teaching in Higher Education, 1990, SCED Paper, p.57.

Leung, D. Y. P. \& Kember, D. (2003) The relationship between approaches to learning and reflection upon practice. Educational Psychology, 23 (1), pp.61-71.

Skogsberg, K. \& Clump, M. (2003). Do psychology and biology majors differ in their study processes and learning styles? College Student Journal, 37 (1), pp.27-33.

Vernon, D.T.A \& Blake, R.L. Does problem-based learning work? A meta-analysis of evaluative research. Acad Med 1993; 68, pp.550-63.

Wendelberger, K.J., Simpson, D.E.\& Biernat, K.A. Problem-based learning in a third-year pediatric clerkship. Teach Learn Med 1996, 8, pp.28-32. 